\title{
Composition of Ethyl Acetate Extracts from Three Plant Materials (Shaddock Peel, Pomegranate Peel, Pomegranate Seed) and Their Algicidal Activities
}

\author{
Hongqiang Wang1, Haiyan Kang ${ }^{1}$, Lieyu Zhang2*, Shuiping Cheng ${ }^{1 * *}$, \\ Hong Liu ${ }^{1}$, Huifeng Liu ${ }^{1}$, Bin Sun ${ }^{1}$ \\ 'School of Municipal and Environmental Engineering, Henan University of Urban Construction, \\ Pingdingshan, Henan province 467036, P.R. China \\ ${ }^{2}$ Chinese Research Academy of Environmental Sciences, Beijing 100012, P.R. China
}

Received: 28 July 2014

Accepted: 28 January 2015

\begin{abstract}
Many studies have involved the isolation and identification of allelochemicals from aquatic plants, but the algicidal properties of terrestrial plants have received less attention. This study aims to identify allelochemicals of ethyl acetate extracts from three plant materials (shaddock peel, pomegranate peel, pomegranate seed) and to investigate their inhibitory effects on Microcystis aeruginosa. The ethyl acetate extracts of the three plant materials were identified by GC-MS. Finally, 19 kinds of compounds (including organic acids, ester, ketone, sterol, etc.) were obtained and eight kinds of organic acids and N-phenyl-2-Naphthalenamine were proved to be allelochemicals. The inhibitory effects of the ethyl acetate extracts were also explored by M. aeruginosa bioassay. This showed that the inhibition percentages of ethyl acetate extracts of the three plant materials on the growth of $M$. aeruginosa were $43.9 \%, 47.5 \%$, and $40.3 \%$, respectively, when the algae were treated at a dosage of $20 \mathrm{mg} / \mathrm{L}$ extracts.
\end{abstract}

Keywords: allelopathic effect, shaddock peel, pomegranate peel, pomegranate seed, Microcystis aeruginosa

\section{Introduction}

Eutrophication is a worldwide problem in aquatic ecosystems and cyanobacterial blooms can cause severe water quality deterioration due to toxin production, hypoxia, off-flavor problems that lead to illness in animals and humans [1-3]. Therefore, the removal of harmful cyanobacterial blooms is a crucial step for the maintenance of safe water supplies and for the safety of aquatic products [4].

*e-mail: zhanglieyu@163.com

**e-mail: shpcheng@foxmail.com
Recent years have seen many studies relating to the isolation and identification of allelochemicals from aquatic plants [5-8], while the algicidal properties of terrestrial plants still get less attention [9]. Up to now, the extracts of many terrestrial plants also show inhibitory effects against cyanobacteria, such as barley straw [10-13], Chinese traditional medicines $[9,14,15]$, and so on.

Pomegranate (Punicagranatum), belonging to the family Punicaceae [16], is one of the oldest edible fruits. It has been cultivated extensively in Mediterranean countries, Iran, India, and to some extent in the U.S. (California), China, Japan, and Russia [17]. Pomegranate peels and seeds 
as a byproduct of pomegranate processing are about 26$30 \%, 20 \%(\mathrm{w} / \mathrm{w})$ of the whole fruit weight, respectively $[18,19]$, and are a good source of secondary products such as tannins, organic acid, polyphenol, and alkaloids [20-22]. Shaddock, like other citrus fruits, has a small edible portion and large amounts of waste materials such as peels and seeds, and peels contain considerable phenolic compounds [23]. At present, the polyphenols have shown significant inhibition to the growth of harmful algae. Therefore, these previous results indicate that the shaddock peel, pomegranate peel, and pomegranate seed could be used as an algicide.

The objectives of this study are to identify the allelochemicals from the ethyl acetate extracts of shaddock peel, pomegranate peel, and pomegranate seed, and to test their algicidal activities.

\section{Materials and Methods}

\section{Preparation of Plant Materials Extracts}

Shaddock peel, pomegranate peels, and seeds were naturally dried on trays away from sunlight at room temperature. The dry weight of peels and seeds were measured and powdered to get 20 mesh size. Five $g$ of the shaddock peel, pomegranate peel, and seed powder were extracted with $100 \mathrm{~mL}$ of ethyl acetate (HPLC) at room temperature $\left(25^{\circ} \mathrm{C}\right)$ for $24 \mathrm{~h}$. The extract was filtered through GF/C glass fibre filters $(47 \mathrm{~mm}, 1.2 \mu \mathrm{m}$, purchased from Whatman Maidstone, UK) for removal of particles. The extracts were first dried with anhydrous sodium sulfate (AR) and then evaporated to dryness by rotary evaporator at $39^{\circ} \mathrm{C}$. The ethyl acetate extracts were stored at $4^{\circ} \mathrm{C}$ until used for GCMS analysis and biological assay.

\section{Identification of Allelochemical}

The dried ethyl acetate extracts were analyzed by GCMS (Agilent computerized system consistiing of a 6890 gas chromatograph coupled to a Agilent 5973N quadrupole mass spectrometer) using a HP-5MS capillary column (30 $\mathrm{m} \times 0.25 \mathrm{~mm} \times 0.25 \mathrm{~mm}$ id). The oven temperature was programmed at $60^{\circ} \mathrm{C}$ (initial temperature maintained $1 \mathrm{~min}$ ) to reach $260^{\circ} \mathrm{C}$ at a rate of $4^{\circ} \mathrm{C} / \mathrm{min}$, kept constant $20 \mathrm{~min}$. Helium was used as carrier gas with a flow rate of 1 $\mathrm{mL} / \mathrm{min}$. Mass fragments of the components were compared to the mass fragmentation data contained in the NIST 02 .

\section{Bioassay}

Axenic Microcystis aeruginosa were obtained from the culture collection of algae at the Institute of Hydrobiology, Chinese Academy of Sciences. The algae were cultured in sterilized BG11 medium (pH 7.4) [24] at $25^{\circ} \mathrm{C}$ with light intensity of 2500 lux, 12:12 h light:dark cycle. The algae were cultured for 4 days to reach the exponential phase with the density of $10^{5}-10^{6}$ cells $/ \mathrm{mL}$, which were used for the assay of growth inhibition.
The dose-response relationships between the allelochemicals and the tested organisms were studied in $50 \mathrm{~mL}$ flasks containing $25 \mathrm{~mL}$ test solution, to which $10^{6}$ cells $\mathrm{m} \cdot \mathrm{L}^{-1}$ of $M$. aeruginosa were inoculated. The tested organisms were exposed, in triplicate, to one concentration level and a control, respectively. The final concentrations of compounds in the test solution were $20 \mathrm{mg} \cdot \mathrm{L}^{-1}$ for ethyl acetate extracts from pomegranate peel, pomegranate seed, and shaddock peel, respectively. The inhibition percentages of each ethyl acetate extract based on cell density of the tested organisms and control were determined after exposure for $72 \mathrm{~h}$. The stock solutions of ethyl acetate extracts were prepared with dimethyl sulfoxide (DMSO, AR), which in test solution was lower than $0.2 \%$ $(\mathrm{v} / \mathrm{v})$. The test results indicated that the concentrations of DMSO added had no effect on the growth of the tested organisms.

\section{Results}

Total ion chromatogram was obtained by gas chromatograph-mass spectrometry (GC-MS) analysis of the ethyl acetate extracts from shaddock peel, pomegranate peel, and pomegranate seed. The chemical composition of the ethyl acetate extracts from three plant materials were listed in Table 1. Nineteen compounds were analyzed and identified by GC-MS, among which fatty acids, phenolic acids, and sterol were primary compositions. The amount and components of three ethyl acetate extracts from shaddock peel, pomegranate peel, and pomegranate seed were different (Table 1).

In order to investigate the allelopathic potential of shaddock peel, pomegranate peel and pomegranate seed, the allelopathic effects of ethyl acetate extracts from three plant materials were determined by bioassay of $M$. aeruginosa. The inhibition percentages of ethyl acetate extracts on $M$. aeruginosa were $47.5 \%, 40.3 \%$ and $43.9 \%$ when the algae were treated by $20 \mathrm{mg} / \mathrm{L}$ extracts of pomegranate peel, pomegranate seed, and shaddock peel, respectively. Hence, these three plant materials exhibited significant anticyanobacterial activities (Table 2).

\section{Discussion}

Allelochemical (lauric, myristic, hexadecanoic, linoleic, oleic, stearic, cis-6-octadecenoic, gallic acid, and Nphenyl-2-naphthalenamine) identified in this study were found to be significantly active against some harmful algae (Table 3). Especially phenolic acid (gallic acid) and unsaturated fatty acid (linoleic, oleic, and cis-6-octadecenoic acid) showed stronger algicidal activities. The 50\% inhibitory concentrations of each compound based on the cell density or chlorophyll $a$ of the tested algae $\left(\mathrm{EC}_{50}\right)$ were determined after algae were exposed for one to seven days. This indicates that these identified compounds might potentially be effective biological algicides and serve as allelochemicals to control nuisance algal growth (Table 3). 
Table 1. The analytical results of ethyl acetate extracts from three plant materials by GC-MS.

\begin{tabular}{|c|c|c|c|c|}
\hline $\begin{array}{l}\text { Rent } \\
\text { time } \\
(\min )\end{array}$ & Compounds & 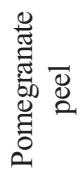 & 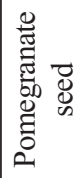 & 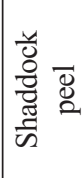 \\
\hline 5.86 & 2-ethyl-1,3-dimethyl-benzene & - & - & + \\
\hline 6.91 & Glycerol & + & - & - \\
\hline 9.30 & Dodecanoic acid & - & - & + \\
\hline 10.05 & Unknown & + & + & - \\
\hline 10.26 & Unknown & + & + & + \\
\hline 10.34 & Unknown & + & + & + \\
\hline 10.37 & Tetradecanoic acid & - & - & + \\
\hline 11.00 & Gallic acid & + & - & + \\
\hline 11.37 & Hexadecanoic acid & + & + & + \\
\hline 11.75 & Heptadecanoic acid & - & - & + \\
\hline 11.89 & cis-6-octadecenoic acid & + & + & + \\
\hline 12.36 & Linoleic acid & - & + & + \\
\hline 12.39 & Oleic acid & + & + & - \\
\hline 12.53 & Stearic acid & + & + & - \\
\hline 12.66 & Unknown & - & + & + \\
\hline 12.76 & Unknown & - & + & + \\
\hline 12.77 & N-phenyl-2-naphthalenamine & + & - & - \\
\hline 13.08 & Unknown & + & + & + \\
\hline 15.00 & $\begin{array}{l}\text { 1,2-benzenedicarboxylic acid, } \\
\text { mono(2-ethylhexyl) ester }\end{array}$ & + & - & - \\
\hline 15.86 & Unknown & - & + & + \\
\hline 19.64 & 1-iodo-octadecane & + & - & - \\
\hline 21.46 & Stigmastan-3,5-diene & + & - & + \\
\hline 22.25 & Unknown & + & - & - \\
\hline 25.30 & Stigmasterol & - & - & + \\
\hline 25.86 & 22,23-dihydro-stigmasterol & + & - & - \\
\hline 26.94 & $\beta$-sitosterol & + & + & + \\
\hline 32.06 & Friedelan-3-one & - & - & + \\
\hline
\end{tabular}

Allelochemicals produced by plant exert inhibitory effects on a variety of algae [6, 25-28] may play important roles in the interaction between plants and phytoplankton species in aquatic ecosystems [8]. The fatty acids and polyphenol show allelopathic antialgal activities $[6,27,29$ 31] and are the main allelochemicals released from the barley straw and Myriophyllum spicatum to inhibit the algal blooms. For example, the well-known allelochemical gallic acid, isolated from many plants, shows antialgal activity
Table 2. Inhibitory effects of ethyl acetate extracts from three plant materials on growth of Microcystis aeruginosa.

\begin{tabular}{|c|c|c|c|}
\hline & $\begin{array}{c}\text { Pomegranate } \\
\text { peel }\end{array}$ & $\begin{array}{c}\text { Pomegranate } \\
\text { seed }\end{array}$ & $\begin{array}{c}\text { Shaddock } \\
\text { peel }\end{array}$ \\
\hline $\begin{array}{c}\text { Inhibition } \\
\text { ratio }\end{array}$ & $47.5 \%$ & $40.3 \%$ & $43.9 \%$ \\
\hline
\end{tabular}

$[29,32]$. Gallic acid is present in macrophytes and can be secreted into surrounding waters to inhibit algae growth [27].

Fatty acids are widely distributed in aquatic and terrestrial environments [33], which could inhibit the growth of harmful algae. To discuss the difference of algae growth inhibition by different fatty acids, it is essential to identify the key structures that induce such effects. Nakai et al. [6] found that:

(i) length of carbon chain

(ii) number of unsaturated linkages

(iii) positions of any double bonds may affect the anticyanobacterial activities of fatty acids.

Fatty acids and polyphenols were the main allelochemicals, the inhibition mechanism had been reported in some of the literature [34-41]. Researchers believe that allelochemicals are toxic to phytoplankton, and the toxic effects are multiple. For example, Wu et al. [34] found that fatty acids primarily affect the plasma membranes, leading to a change in membrane permeability and dissociation of phycobilins from the thylakoids. Severe damage to the plasma membranes would give rise to a disruption of the stressed cells. In addition, allelochemicals can damage cell membranes [35], lyse target cells [36], and influence enzyme activity [37-39], the electron transfer chain [40], and gene expression [41].

\section{Conclusions}

To summarize, the present study isolated and identified allelochemicals of ethyl acetate extracts from three plant materials (shaddock peel, pomegranate peel, pomegranate seed). Allelochemicals (lauric, myristic, hexadecanoic, linoleic, oleic, stearic, cis-6-octadecenoic, gallic acid, and $\mathrm{N}$-phenyl-2-naphthalenamine) identified in this study were found to be significantly active against some harmful algae. Especially phenolic acid (gallic acid) and unsaturated fatty acid (linoleic, oleic and cis-6-octadecenoic acid) showed stronger algicidal activities. The results suggest that these ethyl acetate extracts from three plant materials (shaddock peel, pomegranate peel, pomegranate seed) may serve as environmentally friendly agents for controlling the growth of $M$. aeruginosa.

\section{Acknowledgements}

This work was kindly supported by the National Science-Technology Support Plan Projects of China 
Table 3. $\mathrm{EC}_{50}(\mathrm{mg} / \mathrm{L})$ of 9 allelochemicals on several algae.

\begin{tabular}{|l|c|c|c|c|c|c|}
\hline \multicolumn{1}{|c|}{ Compounds } & $\begin{array}{c}\text { Microcystis } \\
\text { aeruginosa }\end{array}$ & $\begin{array}{c}\text { Chlorella } \\
\text { pyrenoidosa }\end{array}$ & $\begin{array}{c}\text { Scenedesmus } \\
\text { obliquus }\end{array}$ & $\begin{array}{c}\text { Selenastrum } \\
\text { capricornutum }\end{array}$ & $\begin{array}{c}\text { Monoraphidiu } \\
\text { mcontortum }\end{array}$ & $\begin{array}{c}\text { Chlorella } \\
\text { vulgaris }\end{array}$ \\
\hline Lauric acid & $4.563^{\mathrm{a}}$ & $6.265^{\mathrm{a}}$ & $5.813^{\mathrm{a}}$ & $10.36^{\mathrm{b}}$ & $>400^{\mathrm{c}}$ & $>400^{\mathrm{c}}$ \\
\hline Myristic acid & $12.799 \pm 0.471^{\mathrm{d}}$ & $16.003^{\mathrm{a}}$ & $15.977^{\mathrm{a}}$ & $18.65^{\mathrm{b}}$ & $>400^{\mathrm{c}}$ & $>400^{\mathrm{c}}$ \\
\hline Hexadecanoic acid & $17.167 \pm 0.794^{\mathrm{d}}$ & $19.876^{\mathrm{a}}$ & $20.146^{\mathrm{a}}$ & $35.46^{\mathrm{b}}$ & $9.2 \pm 0.6^{\mathrm{c}}$ & $59.1 \pm 1.5^{\mathrm{c}}$ \\
\hline Linoleic acid & $0.042 \pm 0.012^{\mathrm{d}}$ & $0.089^{\mathrm{a}}$ & $0.059^{\mathrm{a}}$ & $17.27^{\mathrm{b}}$ & $8.0 \pm 0.1^{\mathrm{c}}$ & $9.4 \pm 0.2^{\mathrm{c}}$ \\
\hline Oleic acid & $1.332^{\mathrm{a}}$ & $1.475^{\mathrm{a}}$ & $1.406^{\mathrm{a}}$ & $8.08^{\mathrm{b}}$ & $12.1 \pm 0.9^{\mathrm{c}}$ & $12.4 \pm 0.3^{\mathrm{c}}$ \\
\hline Stearic acid & $19.849^{\mathrm{a}}$ & $20.849^{\mathrm{a}}$ & $20.754^{\mathrm{a}}$ & $40.27^{\mathrm{b}}$ & $177 \pm 15^{\mathrm{c}}$ & $200 \pm 25^{\mathrm{c}}$ \\
\hline cis-6-octadecenoic acid & $3.3 \pm 0.4^{\mathrm{f}}$ & & & & & \\
\hline Gallic acid & $1.0^{\mathrm{e}}$ & & & & & \\
\hline N-phenyl-2-naphthalenamine & $5^{\mathrm{a}}$ & & & & & \\
\hline
\end{tabular}

${ }^{a}$ quoted from [42]; ${ }^{\mathrm{b}}$ quoted from [43]; ${ }^{\mathrm{c}}$ quoted from [34]; ${ }^{\mathrm{d}}$ quoted from [44]; ${ }^{\mathrm{e}}$ quoted from [27]; ${ }^{\mathrm{f}}$ quoted from [6]; ${ }^{\mathrm{g}}$ quoted from [45]

(2012BAJ21B06), the National Natural Science Foundation of China (51108447; 51208485), the China Postdoctoral Science Foundation Project (20100471208), the China Postdoctoral Science Special Foundation (201104499), and the Science Foundation of Henan University of Urban Construction (2013JBS008).

\section{References}

1. BRIAND E., GUGGER M., FRANCOIS J. C., BERNARD C., HUMBERT J. F., QUIBLIER C. Temporal variations in the dynamics of potentially microcystin-producing strains in a bloom-forming Planktothrix agardhii (cyanobacterium) population. Appl. Environ. Microb. 74, (12), 3839, 2008.

2. LOPEZ C. B., JEWETT E. B., DORTCH Q., WALTON B. T., HUDNELL H. K. Scientific assessment of freshwater harmful algal blooms. In: Interagency Working Group on Harmful Algal Blooms, Hypoxia, and Human Health of the Joint Subcommittee on Ocean Science and Technology. Washington, DC. 2008.

3. ZHANG M., WANG Z. Q., XU J., LIU Y. Q., NI L. Y., CAO T., XIE P. Ammonium, microcystins, and hypoxia of blooms in eutrophic water cause oxidative stress and C-N imbalance in submersed and floating-leaved aquatic plants in Lake Taihu, China. Chemosphere 82, (3), 329, 2011.

4. SHAO J. H., LI R. H., LEPO J. E., GU J. D. Potential for control of harmful cyanobacterial blooms using biologically derived substances: Problems and prospects. J. Environ. Manage. 125, 149, 2013.

5. HONG Y., HU H. Y., SAKODA A., SAGEHASHI M. Isolation and characterization of antialgal allelochemicals from Arundo donax L. Allelopathy J. 25, (2), 357, 2010.

6. NAKAI S., YAMADA S., HOSOMI M. Anti-cyanobacterial fatty acids released from Myriophyllum spicatum. Hydrobiologia 543, (1), 71, 2005.

7. WANG H. Q., LIANG F., QIAO N., DONG J. X., ZHANG L. Y., GUO Y. F. Chemical composition of volatile oil from two emergent plants and their algae inhibition activity. Pol. J. Environ. Stud. 23, (6), 2371, 2014.

8. ZHANG S. H., CHENG S. P., WANG H. Q., HE F., WU Z. B. Allelopathic interactions between the Potamogeton spp and toxic cyanobacteria (Microcystis aeruginosa). Allelopathy J. 23, (2), 379, 2009.

9. ZHANG C., YI Y. L., HAO K., LIU G. L., WANG G. X. Algicidal activity of Salvia miltiorrhiza Bung on Microcystis aeruginosa - Towards identification of algicidal substance and determination of inhibition mechanism. Chemosphere 93, (6), 997, 2013.

10. BALL A. S., WILLIAMS M., VINCENT D., ROBINSON J. Algal growth control by a barley straw extract. Bioresource Technol. 77, (2), 177, 2001.

11. BARRETT P. R. F., LITTLEJOHN J. W., CURNOW J. Long-term algal control in a reservoir using barley straw. Hydrobiologia 415, 309, 1999.

12. UALLACHÁIN D. Ó., FENTON O. Barley (Hordeum vulgare)-induced growth inhibition of algae: a review. J. Appl. Phycol. 22, (5), 651, 2010.

13. WAYBRIGHT T. J., TERLIZZI D. E., FERRIER M. D. Chemical characterization of the aqueous algistatic fraction of barley straw (Hordeum vulgare) inhibiting Microcystis aeruginosa. J. Appl. Phycol. 21, (3), 333, 2009.

14. YI Y. L., LEI Y., YIN Y. B., ZHANG H. Y., WANG G. X. The antialgal activity of 40 medicinal plants against Microcystis aeruginosa. J. Appl. Phycol. 24, (4), 847, 2012.

15. ZHANG S. L., ZHANG B., XING K. Z., ZHANG X. M., TIAN X. P., DAI W. Inhibitory effects of golden thread (Coptis chinensis) and berberine on Microcystis aeruginosa. Water Sci. Technol. 61, (3), 763, 2010.

16. LANSKY E. P., NEWMAN R. A. Punica granatum (pomegranate) and its potential for prevention and treatment of inflammation and cancer. J. Ethnopharmacol. 109, (2), 177, 2007.

17. FADAVI A., BARZEGAR M., HOSSEIN AZIZI M. Determination of fatty acids and total lipid content in oilseed of 25 pomegranates varieties grown in Iran. J. Food Compos. Anal. 19, (6), 676, 2006.

18. ISMAIL T., SESTILI P., AKHTAR S. Pomegranate peel and fruit extracts: A review of potential anti-inflammatory and anti-infective effects. J. Ethnopharmacol. 143, (2), 397, 2012.

19. JING P., YE T., SHI H. M., SHENG Y., SLAVIN M., GAO B. Y., LIU L. W., YU L. L. Antioxidant properties and phytochemical composition of China-grown pomegranate seeds. Food Chem. 132, (3), 1457, 2012. 
20. GUNDOGDU M., YILMAZ H. Organic acid, phenolic profile and antioxidant capacities of pomegranate (Punica granatum L.) cultivars and selected genotypes. Sci. Hortic. 143, 38, 2012.

21. MIRDEHGHAN S. H., RAHEMI M. Seasonal changes of mineral nutrients and phenolics in pomegranate (Punica granatum L.) fruit. Sci. Hortic. 111, (2), 120, 2007.

22. SAAD H., Charrier-El Bouhtoury F., PIZZI A., RODE K., CHARRIER B., AYED N. Characterization of pomegranate peels tannin extractives. Ind. Crop. Prod. 40, 239, 2012.

23. OBOH G., ADEMOSUN A. O. Shaddock peels (Citrus maxima) phenolic extracts inhibit $\alpha$-amylase, $\alpha$-glucosidase and angiotensin I-converting enzyme activities: A nutraceutical approach to diabetes management. Diabetes \& Metabolic Syndrome: Clinical Research \& Reviews 5, (3), 148, 2011

24. RIPPKA R., DERUELLES J., WATERBURY J. B., HERDMAN M., STANIER R. Y. Generic assignments, strain histories and properties of pure cultures of cyanobacteria. J. Gen. Microbiol. 111, (1), 1, 1979.

25. GAO Y. N., LIU B. Y., XU D., ZHOU Q. H., HU C. Y., GE F. J., ZHANG L. P., WU Z. B. Phenolic compounds exuded from two submerged freshwater macrophytes and their allelopathic effects on Microcystis aeruginosa. Pol. J. Environ. Stud. 20, (5), 1153, 2011.

26. HONG Y., HU H. Y. Effects of the aquatic extracts of Arundo donax L. on the growth of freshwater algae. Allelopathy J. 20, (2), 315, 2007.

27. NAKAI S., INOUEY., HOSOMI M., MURAKAMI A. Myriophyllum spicatum-released allelopathic polyphenols inhibiting growth of blue-green algae Microcystis aeruginosa. Water Res. 34, (11), 3026, 2000.

28. ZHANG S. H., CHENG S. P., SUN P. S., WANG H. Q., WU Z. B. Isolation and identification of antialgal compounds from Potamogeton maackianus by activity-guided fractionation. Allelopathy J. 28, (1), 95, 2011.

29. GROSS E. M., MEYER H., SCHILLING G. Release and ecological impact of algicidal hydrolysable polyphenols in Myriophyllum spicatum. Phytochemistry 41, (1), 133, 1996.

30. PILLINGER J. M., COOPER J. A., RIDGE I. Role of Phenolic Compounds in the antialgal activity of barley straw. J. Chem. Ecol. 20, (7), 1557, 1994.

31. TANG C. S., WAISS Jr A. C. Short-chain fatty acids as growth inhibitors in decomposing wheat straw. J. Chem. Ecol. 4, (2), 225, 1978.

32. PLANAS D., SARHAN F., DUBE L., GODMAIRE H., CADIEUX C. Ecological significance of phenolic compounds of Myriophyllum spicatum. Verh. Internat. Verein. Limnol. 21, 1492, 1981.

33. JANDL G., SCHULTEN H. R., LEINWEBER P. Quantification of long-chain fatty acids in dissolved organic matter and soils. J. Plant Nutr. Soil Sc. 165, (2), 133, 2002.
34. WU J. T., CHIANG Y. R., HUANG W. Y., JANE W. N. Cytotoxic effects of free fatty acids on phytoplankton algae and cyanobacteria. Aquat. Toxicol. 80, (4), 338, 2006.

35. ZHANG T. T., ZHENG C. Y., HU W., XU W. W., WANG H. F. The allelopathy and allelopathic mechanism of phenolic acids on toxic Microcystis aeruginosa. J. Appl. Phycol. 22, (1), 71, 2010

36. LEGRAND C., RENGEFORS K., FISTAROL G. O., GRANÉLI E. Allelopathy in phytoplankton: biochemical, ecological and evolutionary aspects. Phycologia 42, (4), 406, 2003.

37. DZIGA D., SUDA M., BIALCZYK J., CZAJA-PROKOP U., LECHOWSKI Z. The alteration of Microcystis aeruginosa biomass and dissolved microcystin-LR concentration following exposure to plant-producing phenols. Environ. Toxicol. 22, (4), 341, 2007.

38. QIAN H. F., YU S. Q., SUN Z. Q., XIE X. C., LIU W. P., FU Z. W. Effects of copper sulfate, hydrogen peroxide and $\mathrm{N}$-phenyl-2-naphthylamine on oxidative stress and the expression of genes involved photosynthesis and microcystin disposition in Microcystis aeruginosa. Aquat. Toxicol. 99, (3), 405, 2010.

39. SUN X. M., LIU B. Y., LU Z. Y., WU Z. B. Study on oxidative damage to Microcystis aeruginosa mediated by allelochemical pyrogallic acid from submerged macrophytes. China Environmental Science 33, (10), 1835, 2013 [In Chinese].

40. LEU E., KRIEGER-LISZKAY A., GOUSSIAS C., GROSS E. M. Polyphenolic allelochemicals from the aquatic angiosperm Myriophyllum spicatum inhibit photosystem II. Plant Physiol. 130, (4), 2011, 2002.

41. SHAO J. H., WU Z. X., YU G. L., PENG X., LI R. H. Allelopathic mechanism of pyrogallol to Microcystis aeruginosa PCC7806 (Cyanobacteria): From views of gene expression and antioxidant system. Chemosphere 75, (7), 924, 2009.

42. ZHANG T. T., ZHANG C.Y., HE M., WU A. P., NIE L. W. Inhibition on algae of fatty acids and the structure-effect relationship. China Environmental Science 29, (3), 274, 2009 [In Chinese]

43. HU C. Y., GE F. J., ZHANG S. H., LIU B. Y., WANG J., GAO Y. N., WU Z. B. Isolation of antialgal compounds from Potamogeton malaianus and algal inhibitory effects of common fatty acids. Journal of Lake Sciences 22, (4), 569, 2010 [In Chinese]

44. ZHANG T. T., HE M., WU A. P., NIE L. W. Allelopathic effects of submerged macrophyte Chara vulgaris on toxic Microcystis aeruginosa. Allelopathy J. 23, (2), 391, 2009.

45. GENG X. J., FAN Y., WANG X. Q., FU H. L., LAN L. Q. Effects of an allelochemical, N-phenyl-2-naphthylamine, from Eichhornia crassipes on the growth of Microcystis aeruginosa. Journal of Sichuan University (Natural Science Edition) 46, (5), 1493, 2009 [In Chinese]. 
